\title{
Scrolls, Testament and Talmud: Issues of Antisemitism in the Study of Ancient Judaism
}

The study of ancient Judaism raises numerous issues regarding antisemitism such as: Greco-Roman antisemitism and early antisemitic (or anti-Judaic) literature, ${ }^{1}$ early Jewish-Christian relations, ${ }^{2}$ and antagonism to the Jews in Babylonia. ${ }^{3}$ These phenomena continue to be studied by numerous scholars. What has been lacking in research is a meta-analysis that seeks to show how antisemitism has affected the study not only of ancient anti-Judaism but of ancient Judaism and Jewish history in Late Antiquity as a whole.

Aspects of this problem include the effects of antisemitism on descriptive terms for Judaism in Antiquity and Late Antiquity; approaches to periodization within the larger ancient historical framework; construal of Jews and Judaism in light of New Testament images and later anti-Jewish material in the Church Fathers; effects of the Reformation and Protestantism on views of the Jews and Judaism; and numerous such topics. More recently, there has been fundamental questioning of the basic geographical and historical facts of ancient Jewish history as a result of modern Middle Eastern issues, to name just a few of the most prominent problems.

Some might wonder why one would consider the field of Judaic Studies at a conference devoted to antisemitism. At first glance, it would appear that Judaic Studies is itself a strong antidote to anti-Jewish/Judaic prejudice. Indeed such a notion lay behind the rise of the Wissenschaft des Judentums, the scientific study of Judaism, as it developed in Germany and elsewhere in the nineteenth century. ${ }^{4}$ Its earliest advocates thought it could be utilized as a strategy for combating

1 Cf. P. Schäfer, Judeophobia: Attitudes toward the Jews in the Ancient World (Cambridge: Harvard University Press, 1997), 15-210.

2 Cf. P. Frederiksen, Augustine and the Jews: A Christian Defense of the Jews and Judaism (New York: Doubleday, 2008), 64-101.

3 Cf. Y. Gafni, Yehude Bavel bi-Tequfat ha-Talmud (Jerusalem: Zalman Shazar Center, 1990), 40-42, 151-52 where Gafni notes that antagonism came from the Mazdaean priests and not from the common people; R. Kalmin, Jewish Babylonia: Between Persia and Roman Palestine (Oxford: Oxford University Press, 2006), 121-48.

4 See the thorough review of the literature on the Wissenschaft in K. von der Krone and M. Thulin, “Wissenschaft in Context: A Research Essay on the Wissenschaft des Judentums," Leo Baeck Institute Year Book 58 (2013): 249-80. M. A. Meyer, “Two Persistent Tensions within Wissen-

Ә OpenAccess. (C) 2019 Lawrence H. Schiffman, published by De Gruyter. (cc) BY-NC-ND This work is licensed under the Creative Commons Attribution-NonCommercial-NoDerivatives 4.0 License. 
the antisemitic views that penetrated society in nineteenth-century Germany. ${ }^{5}$ It was expected that subjecting Judaism and the history of the Jews to academic research and teaching would attain for it respectability in the "enlightened" society of nineteenth-century Western Europe.

Unfortunately, however, Judaic Studies, or some of its research results, have sometimes been harnessed by antisemites. Even worse, under the Nazis ${ }^{6}$ and the Soviet Union ${ }^{7}$ essentially antisemitic forms of Judaic Studies were conducted under government auspices. Such anti-Jewish approaches were especially present in New Testament scholarship when dealing with Jews and Judaism. ${ }^{8}$ Some of the Nazi-supporting Judaic "scholars" actually transformed themselves into Judaica professors in the post-War era. However, we will see that much of the anti-Judaism that is embodied in Judaic Studies comes rather from perceptions of the field stemming from those who work in related disciplines. In the case of the study of Judaism in Antiquity, to which we are giving most of our attention here, we will see that a kind of academic supersessionism, admittedly with a small letter "s," has resulted from interest in Jews and Judaism in the course of explaining the New Testament and the rise of early Christianity. This, indeed, was the case with the Dead Sea Scrolls. ${ }^{9}$

schaft des Judentums," Modern Judaism 24, no. 2 (2004): 105-19. Its ideology has been discussed in D. N. Myers, "The Ideology of Wissenschaft des Judentums," in History of Jewish Philosophy, ed. D. H. Frank and O. Leaman (London: Routledge, 1997), 706-20.

5 Cf. Ch. Wiese, “'The Best Antidote to Anti-Semitism?? Wissenschaft des Judentums, Protestant Biblical Scholarship, and Anti-Semitism in Germany before 1933," in Modern Judaism and Historical Consciousness: Identities, Encounters, Perspectives, ed. A. Gotzmann and Ch. Wiese (Leiden: Brill, 2007), 145-92.

6 Cf. A. Gerdmar, Roots of Theological Anti-Semitism: German Biblical Interpretation and the Jews, from Herder and Semler to Kittel and Bultmann (Leiden: Brill, 2009), 415-576.

7 Cf. G. Estraikh, "Studies of Jews and Judaism in Post-Stalinist Soviet Union," lecture for the Panel Judaism, Jewish Studies and Antisemitism, Conference “An End to Antisemitism!” University of Vienna, Vienna, February 22, 2018.

8 As an example, see the discussion of the Theologisches Wörterbuch zum Neuen Testament (Theological Dictionary of the New Testament in its English translation), as discussed by J. S. Vos, “Antijudaismus/Antisemitismus im Theologischen Wörterbuch zum Neuen Testament," Nederlands Theologisch Tijdschrift 35 (1984): 89-110; M. Casey, "”Some Anti-Semitic Assumptions in the Theological Dictionary of the New Testament," Novum Testamentum 41, no. 3 (1999): 280 -91; W. A. Meeks, “A Nazi New Testament Professor Reads his Bible: The Strange Case of Gerhard Kittel,” in The Idea of Biblical Interpretation: Essays in Honor of James L. Kugel, ed. H. Najman and J. H. Newman (Leiden: Brill, 2004), 513-44. See especially S. Heschel, Transforming Jesus from Jew to Aryan: Protestant Theologians in Nazi Germany (Tucson: University of Arizona, 1995).

9 Cf. L. H. Schiffman, “Confessionalism and the Study of the Dead Sea Scrolls," Jewish Studies: Forum of the World Union of Jewish Studies 31 (1991): 3-14. 
A related issue is that of periodization and the terms used to describe Judaism in Late Antiquity, Spätjudentums, "late Judaism," being the worst example. ${ }^{10}$ This term bespeaks an assumption that Judaism effectively ceased to be a living organism in Antiquity and ignores the totality of medieval and modern creativity. A second terminological issue pertains to the argument that the term antisemitism should refer only to the racial variety of hatred for Jews that developed in modern times, and that was a major theme in the Holocaust. ${ }^{11}$ The argument goes that ancient forms of Jew hatred should be called anti-Judaism. ${ }^{12}$ Such a term refers not to people but to a conceptual entity, thereby falsely denying that hatred of Jews as people is an ancient phenomenon. ${ }^{13}$ More importantly, use of the term anti-Judaism severs the continuity of hatred of Jews and relieves the ancient historical memory-much of it handed down through the medium of Christianity-of any role in preparing the way for the culmination of anti-Judaism/antisemitism in the Shoah.

In what follows, we will try to flesh out these issues and propose some ways in which the academic field of the study of ancient Judaism can itself help in the fight against antisemitism. This era is uniquely positioned as it occurred during

10 Cf. G. W. E. Nickelsburg, "Anti-Judaism in Christian Theology," Religious Studies Review 4, no. 3 (1978): 161-62; J. D. G. Dunn, "Altering the Default Setting: Re-envisaging the Early Transmission of the Jesus Tradition,” New Testament Studies 49, no. 2 (2003): 141.

11 D. Engel, "Away from a Definition of Antisemitism: An Essay in the Semantics of Historical Description," in Rethinking European Jewish History, ed. M. J. Rosman and J. Cohen (Oxford: Littman Library of Jewish Civilization, 2009), 30-53 argues against the use of this term as a category in Jewish history, claiming that there is no demonstrated unity to anti-Jewish actions over the course of history. See the critique of this distinction by S. Heschel, "Historiography of Antisemitism versus Anti-Judaism: A Response to Robert Morgan," Journal of the Study of the New Testament 33, no. 3 (2011): 257-79; J. Favret-Saada, "A Fuzzy Distinction: Anti-Judaism and Anti-Semitism," Hau: Journal of Ethnographic Theory 4, no. 3 (2014): 335-40; and the more popular discussion in E. Wexler, "The Semantics of Anti-Semitism," Moment Magazine, May 12, 2017. https://www.momentmag.com/ semantics-anti-semitism/. Cf. also D. Engel, "The Concept of Antisemitism in the Historical Scholarship of Amos Funkenstein," Jewish Social Studies: New Series 6, no. 1: Amos Funkenstein's Perceptions of Jewish History: An Evaluation of his Work by his Students (1999): 111-29.

12 This is the view of G. I. Langmuir, Toward a Definition of Antisemitism (Berkeley: University of California Press, 1990), 57-99 and is the overall approach taken in R. Chazan, From Anti-Judaism to Anti-Semitism: Ancient and Medieval Christian Constructions of Jewish History (New York: Cambridge University Press, 2016), 3-106.

13 Cf. Schäfer, Judeophobia, 197-211. 
the so-called matrix of Christianity, the "crossroads," or, to use another term, at the "parting of the ways." 14

In order to understand this problem, it is necessary to say a bit about the standard explanations of the origins of Judaic Studies as it is practiced in modern universities. ${ }^{15}$ The field has a kind of Heilsgeschichte, a "sacred history," that certainly accompanied its rise in Israel and in the United States. According to this sacred history, the field developed out of the Wissenschaft des Judentums. ${ }^{16}$ This quest for engaging in the scientific study of Jewish history, literature, thought, and even material culture developed in some ways parallel with the movement for religious reform in Germany and elsewhere in Western Europe. ${ }^{17}$ The earliest proponents sought to bring methods of philological study, known to them primarily from the field of Classics, to bear on Jewish texts and to bring as well a historical perspective. They argued forcefully for the need to establish chairs in Jewish studies at German universities, a dream not fulfilled until after the Holocaust. Further, and very important for our purposes today, they argued that the integration of Jewish subjects into mainstream academic institutions would serve to normalize the Jews in society ${ }^{18}$ and, thereby, to stem the antisemitism that at the very same time was being transformed into its modern racial-and indeed lethal-variety. There is certainly no question that the Wissenschaft played a major role in the development of Judaic Studies and its intellec-

14 For a critique of this term and its implications, see J. Lieu, “The Parting of the Ways': Theological Construct or Historical Reality?" Journal for the Study of the New Testament 17, no. 56 (1995): 101-19. Such a critique is the overall message of the essays in A. H. Becker and A. Y. Reed, eds., The Ways that Never Parted: Jews and Christians in Late Antiquity and the Early Middle Ages (Tübingen: Mohr Siebeck, 2003). See their "Introduction: Traditional Models and New Directions," 1-24.

15 Since I will be concentrating on my own area of research, it is possible that some of the issues raised here may not apply across the full chronology and varying methodologies of Jewish Studies. Nevertheless, some concerns will be easily transferred to issues my colleagues face in their own particular specialties.

16 For a useful corrective, see S. Imhoff, "Reflections on Jewish Studies," Bulletin for the Study of Religion 43, no. 4 (2014): 25-26, who emphasized the 1960s as the real foundation point of Judaic Studies in American universities.

17 Cf. I. Schorsch, From Text to Context: The Turn to History in Modern Judaism (Hanover: Brandeis University Press, 1994), 303-33; M. A. Meyer, “Jewish Religious Reform and Wissenschaft des Judentums: The Positions of Zunz, Geiger, and Frankel,” Leo Baeck Institute Year Book 16, no. 1 (1971): 19-41; M. A. Meyer, Response to Modernity: A History of the Reform Movement in Judaism (New York: Oxford University Press, 1988), 75-77.

18 N. N. Glatzer, "The Beginnings of Modern Jewish Studies," in Studies in Nineteenth-Century Jewish Intellectual History, ed. A. Altmann (Cambridge: Harvard University Press, 1964), 39-40. 
tual character. But there were several other aspects as well that will be important for us.

In particular, biblical studies was a very strong influence on the field, ${ }^{19}$ especially as it relates to the periods of Antiquity and Late Antiquity, that is, the era of the Hebrew Bible, Second Temple, and rabbinic periods. Here we have to reckon with two things: First, the study of the Old Testament (as opposed to the Jewish Tanakh) was a field in which Jews were excluded in Europe until after the Holocaust. Inroads occurred in the U.S. and, together with the field of archaeology, biblical studies had an enormous impact, especially in Israel. ${ }^{20}$ When I entered the field seeking employment in the early 1970s, we were warned that many American departments of religion simply would not hire Jews to teach the Old Testament. Of course, in many European universities, Hebrew Bible is only taught in Protestant or Catholic theological faculties where adherence to the appropriate faith is a sine qua non for appointment.

Second, there is another half to biblical studies: New Testament and the origins of Christianity. The reality is that the study of Judaism in Late Antiquity in university settings emerged primarily not from the Wissenschaft but rather from the quest for New Testament background, a quest that can be traced to a variety of trends in modern Protestantism, especially the search for what is termed "Christian origins."21 Here we deal for the most part not with antisemitism in its usual sense but with a kind of intellectual supersessionism in which certain models have become primary and have influenced the way in which the field is pursued. ${ }^{22}$ To some extent, this Christianization of ancient Judaism results from both good and bad causes. The good, especially in the years following the Holocaust, is a tremendous interest on the part of Christian scholars in understand-

19 See N. M. Sarna, "The Bible and Judaic Studies," in The Teaching of Judaica in American Universities: The Proceedings of a Colloquium, ed. L. Jick (New York: Ktav, 1970), 35-40.

20 O. Bar-Yosef and A. Mazar, “Israeli Archaeology,” World Archaeology 13, no. 3 (1982): 310 - 25. For critiques of Israeli archaeology, highlighting nationalistic tendencies, see R. S. Hallote and A. H. Joffe, “The Politics of Israeli Archaeology: Between 'Nationalism' and 'Science' in the Age of the Second Republic," Israel Studies 7, no. 3 (2002): 84-116, and T. Shay, "Israeli Archaeology -Ideology and Practice," Antiquity 63, no. 241 (1989): 768-72.

21 B. Schwartz, "Christian Origins: Historical Truth and Social Memory," in Memory, Tradition, and Text: Use of the Past in Early Christianity, ed. A. Kirk and T. Thatcher (Atlanta: Society of Biblical Literature, 2005), 43-78. See also L. Hurtado, "Interactive Diversity: A Proposed Model of Christian Origins,” The Journal of Theological Studies 64, no. 2 (2013): 445-47 for recent scholarship.

22 See the critique of P. Fredriksen, "Mandatory Retirement: Ideas in the Study of Christian Origins whose Time has Come to Go," Studies in Religion/ Sciences Religieuses 35, no. 2 (2006): 231-46. 
ing the Jewishness of Jesus and earliest Christianity. This interest has, in turn, helped tremendously in the fight against antisemitism, especially in Christian denominations and institutions. That is the good part.

The problem, however, comes when the conceptualization of the field is based on Christian models, and when sometimes these models are essentially anti-Jewish. Let me take an example that pertains to periodization. A fundamental question regarding the study of ancient Judaism is when the transition takes place between what scholars call "Israelite religion" and "Judaism." This question itself is one that runs against the self-understanding of Judaism that sees a continuity of development, even with certain changes, from the Iron Age through the Persian, Hellenistic, and Roman periods. Standard works such as Schürer's History of the Jewish People in the Time of Jesus Christ (1886-90), note the title carefully, revised edition, (1973-97) simply assumed, in the original edition, that a hiatus had occurred when the Jews went off course and rejected the messiahship of Jesus. ${ }^{23}$

The anti-Judaic character of this argument was clear already when George Foot Moore, Judaism in the First Centuries of the Christian Era: The Age of the Tannaim (1927), focusing on certain features of early Second Temple Judaism, decided that the transition had occurred at the time of Ezra and Nehemiah. ${ }^{24}$ Yet, ironically, for many scholars, the destruction of the Second Temple became a sort of stand-in for the crucifixion. No longer arguing for the anti-Jewish claim that Judaism came into being when Jews abandoned the true religion of biblical Israel by rejecting Jesus, the date was simply transferred to a few years later, still marking the transition at virtually the same point. This view was followed, mirabile dictu, by Jacob Neusner in the form of an assumption that underlies most of his work, namely, that the destruction of the Temple served as a watershed for the development of Rabbinic Judaism. ${ }^{25}$ By this time, what was originally an antisemitic trope survived to a great extent because the results of the study of the Dead Sea Scrolls and other Second Temple literature had remained the property of a different academic "sect" from that which studied rabbinic literature. Rabbinics had only overcome the anti-Jewish stereotypes that accompanied it and entered into the university environment in the mid-twentieth century. So here we have an example of scholars seeking to free themselves of an antisemitic, su-

23 Cf. G. F. Moore, “Christian Writers on Judaism,” Harvard Theological Review 14, no. 3 (1921): 237-41.

24 Cf. G. F. Moore, Judaism in the First Centuries of the Christian Era (New York: Schocken, 1971), $14-26$.

25 However, see his How Important Was the Destruction of the Second Temple in the Formation of Rabbinic Judaism? (Lanham: University Press of America, 2005). 
persessionist trope still falling into the same trap laid for them by their antisemitic predecessors.

Perhaps the best example of this kind of academic supersessionism plagued my chosen field, the study of the Dead Sea Scrolls. ${ }^{26}$ Here we saw a field emerge in which an amazingly important corpus of early Jewish writings was harnessed to provide a proto-history for Christianity and studied in an imbalanced manner and without serious attention to the real significance of the material. This, of course, is an overstatement, since from the very beginning some Jewish, Israeli, and non-Jewish Judaic scholars of eminence were involved. However, the maintenance of a monopoly on publication and a virtual monopoly on interpretation during the early years of Scrolls studies encouraged what I have called the Christianization of the Scrolls. ${ }^{27}$ Some members of the original Scrolls publication team and scholars close to them have been known to have subscribed to an attitude of anti-Judaism. ${ }^{28}$ One prominent scholar, writing about early attempts to purchase scrolls from the Bedouin, openly describes the competition with Israeli archaeologists as a struggle to keep the Scrolls out of the hands of the Israelis. ${ }^{29}$ Even so, for the most part we were dealing with a kind of academic supersessionism, pursued even by those friendly to the Jewish people and respectful of Judaism.

This Christianization of the Scrolls led to the creation of a caricatured construct of the Essenes meant to provide a new solution to the difficult problem of Christian origins. The relevance of the material for the history of Judaism was given way insufficient attention, and those qualified to interpret it in that manner were for over forty years kept at arm's length from the still unpublished material and not admitted to the charmed inner circle of Scrolls scholars. All kinds of exaggerated accounts of parallels to the New Testament or to early Christian monasteries were highly influential on the interpretation of the Scrolls. Most Scrolls research on the quarter of the material (measured in words) that had been published was carried on as if the Jewish context had no independent sig-

26 For a detailed history of the early years of the field, see W. Fields, The Dead Sea Scrolls: A Full History, vol. 1 (Leiden: Brill, 2009).

27 Cf. L. H. Schiffman, Reclaiming the Dead Sea Scrolls: The History of Judaism, the Background of Christianity, the Lost Library of Qumran (Philadelphia: Jewish Publication Society, 1994), $16-19$.

28 Cf. J. Noble Wilford, “Dead Sea Scrolls Editor's Exit Tied to Anti-Jewish Remarks," The New York Times, December 12, 1990, https://www.nytimes.com/1990/12/12/world/dead-sea-scrollseditor-s-exit-tied-to-anti-jewish-remarks.html.

29 Cf. J. C. Trevor, The Dead Sea Scrolls: A Personal Account (Upland: Upland Commercial Printers, 1988), 83-84, 115, 125, 137-38, 147. 
nificance. Jewish Dead Sea Scrolls study essentially stood as an almost independent field, for example, using its own abbreviation system for the Scrolls that differed from those in use among Christian colleagues. ${ }^{30}$ The net effect of the Christianization of the Dead Sea Scrolls was twofold: First, materials of primary importance for understanding the history of Judaism, such as the halakhic texts, were placed on the back burner. Second, it led to a skewed view of the Dead Sea sectarians emphasizing their supposedly monastic character and their apocalyptic messianism.

This trend was reversed by the entry of a generation of scholars, Jewish and Christian, devoted to properly contextualizing the material and only then using it to understand the history of Judaism and the background of Christianity. In fact, the study of the Scrolls more recently has made a positive contribution to Jewish Christian relations. ${ }^{31}$ In my view, the turning point was the recovery of the Temple Scroll by Yigael Yadin in 1967 and its subsequent publication in Hebrew and then English editions..$^{32}$ Nevertheless, the early study of this field was highly confessionalized and the victim of a kind of intellectual supersessionism that greatly warped its significance.

The problem we have been talking about is not limited to the influence of the study of Christianity on the framing of Jewish studies. There is also a kind of Middle Eastern academic supersessionism that needs to be recognized. Here we need to remember that in many North American universities, partly because of U.S. government critical language programs, ${ }^{33}$ Hebrew and, hence, Judaic Studies, often found its way to departments or programs in Middle Eastern or Near Eastern Studies. This is the third point of origin of Jewish Studies in the U.S. (besides Wissenschaft and biblical studies). I spent my first fifteen years at NYU in the Department of Near Eastern Languages and Literatures, closely affiliated with the Hagop Kevorkian Center for Near Eastern Studies. The department taught Hebrew, Arabic, Persian, ancient Near Eastern languages, and attendant literature and history courses. While absolutely none of my colleagues was an

30 See the list of abbreviations in Y. Yadin, The Scroll of the War of the Sons of Light against the Sons of Darkness (Oxford: Oxford University Press, 1962), xvii-xviii.

31 Cf. E. Schuller, "The Dead Sea Scrolls and Jewish-Christian Dialogue," in From Judaism to Christianity: Tradition and Transition, A Festschrift for Thomas H. Tobin, S.J., on the Occasion of His Sixty-fifth Birthday, ed. P. Walters (Leiden: Brill, 2010), 43-58.

32 Cf. Y. Yadin, Megillat ha-Miqdash, 3 vols. (Jerusalem: The Israel Exploration Society and the Shrine of the Book, 1977); The Temple Scroll, 3 vols. and suppl. rev. ed. (Jerusalem: The Israel Exploration Society and the Shrine of the Book, 1983).

33 Hebrew is no longer listed as a critical language. Its exclusion and the continued inclusion of Arabic and Persian created inequities regarding graduate financial support in some of these departments. 
antisemite, the department was arranged according to what was essentially an Islamic intellectual framework. Jewish studies, therefore, were significant for study of the period of the Jāhiliyah, the pre-Islamic period of ignorance that preceded the prophecy of Mohammed. ${ }^{34}$ Further, Jewish studies were seen as essential for understanding the medieval Middle East and, therefore, effectively looked at in the department as a "protected minority" (dhimmi) in the world of Islam (dar el-Islam). ${ }^{35}$ Those of us who were in Jewish Studies had no choice but to leave that structure in order to create the Skirball Department of Hebrew and Judaic Studies. This expansion allowed Judaic Studies to encompass the full historical, cultural, religious and geographical experience of the Jews. Essentially, the former structure was an intellectually supersessionist approach that was pursued unconsciously by friendly colleagues.

A related problem results from false anti-Jewish construal of rules or laws of ancient Judaism that result from faulty New Testament exegesis. The New Testament is an excellent source for all kinds of historical information about Jews and Judaism in Antiquity. However, the tendency to create "constructions" of Judaism in the image of New Testament anti-Jewish polemic often results in highly skewed pictures of ancient Jewish practice. Let me just mention one example. In the commentaries and academic discussion of the hemorrhaging (more accurately bleeding) woman mentioned in the Gospels (Mt 9:20-22, Mk 5:25-34, Luke 8:43-48), one finds two fundamental interlocking misconceptions. First, many commentators assume that someone who was ritually impure would be totally segregated from the rest of the community. They fail to understand that most varieties of ritual impurity require only that the impure person abstain from going to the Jerusalem Temple or eating of sacrificial offerings. Otherwise, throughout the country, in Judea or the Galilee, their behavior would be totally like that of anyone else. Menstrually impure women were not separated but simply abstained from sexual relations until purification. In this case, however, there is a much worse element. It is claimed, even by modern scholars, that the state of impurity in which this unfortunate woman remained because of a continuous flow of blood was a result of the generally misogynist society in which she lived..$^{36}$ Not only is this a false construal of the ancient ritual reality,

34 Cf. E. A. Doumato and B. D. Cannon, Oxford Encyclopedia of the Islamic World, "Jāhilīyah" (Oxford: Oxford University Press, 2009).

35 See F. Astren, Encyclopedia of the Jews in the Islamic World 2, "Dhimma” (Leiden: Brill, 2010) for the relevance of this status to the Jewish community under Islam.

36 See L. H. Schiffman, "Matthew 9:20 - 22: 'And Behold, a Woman Who Had Suffered from a Hemorrhage'-The Bleeding Woman in Matthew, Mark, and Luke," in The Gospels in First-Century Judaea: Proceedings of the Inaugural Conference of Nyack College's Graduate Program in An- 
but the claim that ancient Jewish society was misogynist is totally belied by the position women played in the Jewish communities of the land of Israel and the Diaspora, even according to New Testament documents. ${ }^{37}$ What is most upsetting, however, is that some of the modern scholarly works that deal with this passage and others like it, as a result of a false assumption, morph into presentist screeds against an ancient culture that are effectively screeds against the contemporary traditional Jewish community. ${ }^{38}$ All this results from analysis of the Judaism that lies behind the New Testament narratives that is conducted in isolation from serious academic Judaic Studies.

To be sure, prejudices regarding the Talmud, many stemming from medieval antisemitic tracts and now propagated on internet sites, had major effects on retarding the development of the academic study of Rabbinic literature. One might argue today that the entry of the study of rabbinic literature and thought into the academic world is a result of the gradual overturning of the antisemitism of the past. Talmudic studies, a field that clearly lies at the core of Judaism's own selfunderstanding, was among the last of the fields of Judaica to find a home in the modern academy. It is hard not to recognize here the influence of the enormous anti-Talmudic literature that came into being primarily in the Middle Ages, ${ }^{39}$ from the thirteenth century on, ${ }^{40}$ and that continued to be created under Nazis $^{41}$ and Communists. ${ }^{42}$ Such originally antisemitic terms as "legalism" and "rabbinism" still haunt the field, often used by Jews and non-Jews with very positive views of Judaism and of rabbinic literature. Further, it would not be fair in this discussion to fail to admit that within the various groups and subgroups of the Jewish community, that is, the various religious movements, there is severe difference of opinion about the authority of the Talmud and its related litera-

cient Judaism and Christian Origins, August 29, 2013, ed. R. S. Notley and J. P. García (Leiden: Brill, 2016), 5-19.

37 Cf. L. J. Archer, Her Price is Beyond Rubies: The Jewish Woman in Graeco-Roman Palestine (Sheffield: JSOT-Press, 1990) and T. Ilan, Jewish Women in Greco-Roman Palestine: An Inquiry into Image and Status (Tübingen: Mohr Siebeck, 2006).

38 Cf. Schiffman, "Matthew 9:20-22," 8-10 and n. 8. On feminist antisemitic New Testament scholarship, see J. Plaskow, "Feminist Anti-Judaism and the Christian God," Journal of Feminist Studies in Religion 7, no. 2 (1991): 99-108.

39 See J. Friedman, J. C. Hoff, and R. Chazan, The Trial of the Talmud: Paris, 1240 (Toronto: Pontifical Institute of Mediaeval Studies, 2012), 1-168.

40 Cf. Chazan, From Anti-Judaism to Anti-Semitism, 109-200.

41 Cf. A. Steinweis, Studying the Jew: Scholarly Antisemitism in Nazi Germany (Cambridge: Harvard University Press, 2006), 7-151.

42 The prime example is J. Neusner, Soviet Views of Talmudic Judaism: Five Papers by Yu. A. Solodukho in English Translation (Leiden: Brill, 1973). 
ture. ${ }^{43}$ For this reason, some spirited internal arguments may themselves sound as if they were also infected with the anti-Talmudism of historical antisemitism. While the recent New Perspective on Paul has proposed new interpretations for a variety of New Testament passages, ${ }^{44}$ it has yet to seep into some of the stereotypes of rabbinic Judaism that were created in the image of older interpretations of some of those same Pauline passages.

Let me now balance this view of academia with some of the enormous accomplishments that have occurred since the Holocaust. The manifestations of antisemitism in the study of ancient Judaism, whether intentional or simply the result of bad scholarship, are not the entire story. The horrendous tragedy of the Holocaust seems to have brought in its wake a realization in many circles that the anti-Judaism and antisemitism of the past contributed in various ways to the attempt to eradicate the Jewish people. This realization, in turn, has clearly been the stimulus for much of the growth of Judaic Studies in Europe and in Christian academic institutions in the United States. Vatican II and conscious moves by other Christian groups have also contributed to much more positive understandings of ancient Judaism. In Dead Sea Scrolls research, the monopoly on the right to hold texts for publication was broken in 1991, and the field expanded to include Jewish and Israeli scholars, some with expertise in Jewish law. This has had positive effects on the overall discussion of the development of Judaism from the Hebrew Scriptures, through the Second Temple period, to the Mishnah, as well as its role in understanding the Second Temple background of the New Testament.

After considering the biases once rampant in Judaic studies, we strongly advocate including the study of modern meta-issues in courses dealing with early Judaism and Christianity so as to make students aware of these pitfalls. Here we have in mind creating a sense among students as future citizens and, in some cases, future clergy or scholars, of how prejudiced points of view on the very specific issues that relate to early Judaism and Christianity can be factors in creating a climate of hatred and antisemitism. Students should be sensitized so as to be suspicious in their reading of precisely where these issues can be found and should be encouraged to see such views for what they are.

We further propose asking academic series and journal editors as well as publishers of more popular works to participate in workshops aimed at sensitizing them to these issues. The problems we are talking about are not obvious;

43 Cf. Meyer, Response to Modernity, 81-83, 92-93, 120-22.

44 Cf. E. P. Sanders, Paul and Palestinian Judaism (Minneapolis: Fortress, 1977); J. D. G. Dunn, The Theology of Paul the Apostle (Grand Rapids: Eerdmans, 1998); J. D. G. Dunn, The New Perspective on Paul (Tübingen: Mohr Siebeck, 2005). 
they do not come with antisemitic vocabulary or wearing the hoods of the Ku Klux Klan. Rather, they often are simply the result of misunderstanding and faulty scholarship. However, editors and publishers should know how to distinguish them and to ask for their correction.

We can learn a lot from the case of the Dead Sea Scrolls: all kinds of misunderstandings were possible when the core scholars working on the material was limited to an essentially judenrein group. As soon as the field began to function in an open and interconfessional manner, with scholars coming from different backgrounds learning from each other and about one another, the problem essentially evaporated and the Qumran Scrolls became a force for positive developments in Jewish-Christian relations. This is a very important lesson. Positive cooperation and exchange of ideas will always win over religious prejudice.

Finally, we will propose that sessions regarding such issues be part of academic conferences in all relevant areas. There is a false notion among those of us who study Antiquity to the effect that relevance represents the dissolution of scholarship. This notion has to be overcome. The contribution of scholarship to the elimination of antisemitism and other prejudices has to be one of its explicit purposes. And the interchange of ideas about how antisemitism may still hide among the building blocks of contemporary scholarship, let alone be present in modern publications, needs to be faced and discussed.

So-called "scholarship" was harnessed by some in the past to support hatred of Jews and others, so as we seek to extirpate antisemitism, scholars must acknowledge the prejudices of the past and seek by all means to uproot them. In both our teaching and research, we must accept our collective responsibility to improve the world in which we live and work. Scholarship in many fields, Judaism in ancient times being one of them, needs to face the antisemitism of the past and work to fight the antisemitism of today.

Lawrence H. Schiffman is the Judge Abraham Lieberman Professor and Director of the Global Network for Advanced Research in Jewish Studies at New York University. He is a specialist in the Dead Sea Scrolls and ancient Judaism, a member and past chair of the International Jewish Committee for Interreligious Consultations and has written on ancient antisemitism and Jewish Christian relations.

\section{Bibliography}

Archer, Léonie J. Her Price is Beyond Rubies: The Jewish Woman in Graeco-Roman Palestine. Sheffield: JSOT-Press, 1990. 
Astren, Fred. Encyclopedia of the Jews in the Islamic World, vol 2. "Dhimma." Leiden: Brill, 2010.

Bar-Yosef, Ofer, and Amihai Mazar. "Israeli Archaeology." World Archaeology 13, no. 3 (1982): $310-25$.

Becker, Adam H., and Annette Yoshiko Reed. "Introduction: Traditional Models and New Directions." In The Ways that Never Parted: Jews and Christians in Late Antiquity and the Early Middle Ages, edited by Adam H. Becker and Annette Yoshiko Reed, 1-34. Tübingen: Mohr Siebeck, 2003.

Casey, Maurice. "Some Anti-Semitic Assumptions in the Theological Dictionary of the New Testament." Novum Testamentum 41, no. 3 (1999): 280-91.

Chazan, Robert. From Anti-Judaism to Anti-Semitism: Ancient and Medieval Christian Constructions of Jewish History. New York: Cambridge University Press, 2016.

Chazan, Robert, Jean Hoff, and John Block Friedman. The Trial of the Talmud: Paris, 1240. Toronto: Pontifical Institute of Mediaeval Studies, 2012.

Doumato, Eleanor A., and Byron D. Cannon. Oxford Encyclopedia of the Islamic World. "Jāhilīyah." Oxford: Oxford University Press, 2009.

Dunn, James D. G. "Altering the Default Setting: Re-envisaging the Early Transmission of the Jesus Tradition." New Testament Studies 49, no. 2 (2003): 139-75.

Dunn, James D. G. The New Perspective on Paul. Tübingen: Mohr Siebeck, 2005.

Dunn, James D. G. The Theology of Paul the Apostle. Grand Rapids: Eerdmans, 1998.

Engel, David. "Away from a Definition of Antisemitism: An Essay in the Semantics of Historical Description." In Rethinking European Jewish History, edited by Moshe J. Rosman and Jeremy Cohen, 30-53. Oxford: Littman Library of Jewish Civilization, 2009.

Engel, David. "The Concept of Antisemitism in the Historical Scholarship of Amos Funkenstein." Jewish Social Studies: New Series 6, no. 1: Amos Funkenstein's Perceptions of Jewish History: An Evaluation of his Work by his Students (1999): 111-29.

Estraikh, Gennady. "Studies of Jews and Judaism in Post-Stalinist Soviet Union." Lecture for the Panel Judaism, Jewish Studies and Antisemitism, Conference "An End to Antisemitism!" University of Vienna, Vienna, February 22, 2018.

Favret-Saada, Jeanne. "A Fuzzy Distinction: Anti-Judaism and Anti-Semitism." Hau: Journal of Ethnographic Theory 4, no. 3 (2014): 335-40.

Fields, Weston W. The Dead Sea Scrolls: A Full History, vol. 1. Leiden: Brill, 2009.

Frederiksen, Paula. Augustine and the Jews: A Christian Defense of the Jews and Judaism. New York: Doubleday, 2008.

Frederiksen, Paula. "Mandatory Retirement: Ideas in the Study of Christian Origins whose Time has Come to Go." Studies in Religion / Sciences Religieuses 35, no. 2 (2006): $231-46$.

Gafni,Yeshayahu [Isaiah]. Yehude Bavel bi-Tequfat ha-Talmud. Jerusalem: Zalman Shazar Center, 1990.

Gerdmar, Anders. Roots of Theological Anti-Semitism: German Biblical Interpretation and the Jews, from Herder and Semler to Kittel and Bultmann. Leiden: Brill, 2009.

Glatzer, Nahum N. "The Beginnings of Modern Jewish Studies.” In Studies in Nineteenth-Century Jewish Intellectual History, edited by Alexander Altmann, 27-45. Cambridge: Harvard University Press, 1964. 
Hallote, Rachel S., and Alexander H. Joffe. "The Politics of Israeli Archaeology: Between 'Nationalism' and 'Science' in the Age of the Second Republic." Israel Studies 7, no. 3 (2002): 84-116.

Heschel, Susannah. "Historiography of Antisemitism versus Anti-Judaism: A Response to Robert Morgan." Journal of the Study of the New Testament 33, no. 3 (2011): 257-79.

Heschel, Susannah. Transforming Jesus from Jew to Aryan: Protestant Theologians in Nazi Germany. Tucson: University of Arizona, 1995.

Hurtado, Larry. “Interactive Diversity: A Proposed Model of Christian Origins." The Journal of Theological Studies 64, no. 2 (2013): 445-62.

Ilan, Tal. Jewish Women in Greco-Roman Palestine: An Inquiry into Image and Status. Tübingen: Mohr Siebeck, 2006.

Imhoff, Sarah. "Reflections on Jewish Studies." Bulletin for the Study of Religion 43, no. 4 (2014): 25-29.

Kalmin, Richard. Jewish Babylonia: Between Persia and Roman Palestine. Oxford: Oxford University Press, 2006.

von der Krone, Kerstin, and Mirjam Thulin. "Wissenschaft in Context: A Research Essay on the Wissenschaft des Judentums." Leo Baeck Institute Year Book 58 (2013): 249-80.

Langmuir, Gavin I. Toward a Definition of Antisemitism. Berkeley: University of California Press, 1990.

Lieu, Judith. “'The Parting of the Ways': Theological Construct or Historical Reality?” Journal for the Study of the New Testament 17, no. 56 (1995): 101-19.

Meeks, Wayne A. "A Nazi New Testament Professor Reads his Bible: The Strange Case of Gerhard Kittel." In The Idea of Biblical Interpretation: Essays in Honor of James L. Kugel, edited by Hindy Najman and Judith H. Newman, 513-44. Leiden: Brill, 2004.

Meyer, Michael A. "Jewish Religious Reform and Wissenschaft des Judentums: The Positions of Zunz, Geiger, and Frankel.” Leo Baeck Institute Year Book 16, no. 1 (1971): $19-41$.

Meyer, Michael A. Response to Modernity: A History of the Reform Movement in Judaism. New York: Oxford University Press, 1988.

Meyer, Michael A. "Two Persistent Tensions within Wissenschaft des Judentums." Modern Judaism 24, no. 2 (2004): 105-19.

Moore, George Foot. "Christian Writers on Judaism." Harvard Theological Review 14, no. 3 (1921): $197-254$.

Moore, George Foot. Judaism in the First Centuries of the Christian Era. New York: Schocken, 1971.

Myers, David N. "The Ideology of Wissenschaft des Judentums." In History of Jewish Philosophy, edited by Daniel H. Frank and Oliver Leaman, 706-20. London: Routledge, 1997.

Neusner, Jacob. How Important Was the Destruction of the Second Temple in the Formation of Rabbinic Judaism? Lanham: University Press of America, 2005.

Neusner, Jacob. Soviet Views of Talmudic Judaism: Five Papers by Yu. A. Solodukho in English Translation. Leiden: Brill, 1973.

Nickelsburg, George W. E. "Anti-Judaism in Christian Theology.” Religious Studies Review 4, no. 3 (1978): 161-67.

Noble Wilford, John. "Dead Sea Scrolls Editor's Exit Tied to Anti-Jewish Remarks." The New York Times, December 12, 1990. https://www.nytimes.com/1990/12/12/world/dead-seascrolls-editor-s-exit-tied-to-anti-jewish-remarks.html. 
Plaskow, Judith. "Feminist Anti-Judaism and the Christian God." Journal of Feminist Studies in Religion 7, no. 2 (1991): 99-108.

Sanders, E. P. Paul and Palestinian Judaism: A Comparison of Patterns of Religion. Minneapolis: Fortress, 1977.

Sarna, Nahum M. "The Bible and Judaic Studies." In The Teaching of Judaica in American Universities: The Proceedings of a Colloquium, edited by Leon Jick, 33-40. New York: Ktav, 1970.

Schäfer, Peter. Judeophobia: Attitudes toward the Jews in the Ancient World. Cambridge: Harvard University Press, 1997.

Schiffman, Lawrence H. "Confessionalism and the Study of the Dead Sea Scrolls." Jewish Studies: Forum of the World Union of Jewish Studies 31 (1991): 3-14.

Schiffman, Lawrence H. "Matthew 9:20-22: 'And Behold, a Woman Who Had Suffered from a Hemorrhage'-The Bleeding Woman in Matthew, Mark, and Luke." In The Gospels in First-Century Judaea: Proceedings of the Inaugural Conference of Nyack College's Graduate Program in Ancient Judaism and Christian Origins, August 29, 2013, edited by R. Steven Notley and Jeffrey P. García, 5-19. Leiden: Brill, 2016.

Schiffman, Lawrence H. Reclaiming the Dead Sea Scrolls: The History of Judaism, the Background of Christianity, the Lost Library of Qumran. Philadelphia: Jewish Publication Society, 1994.

Schorsch, Ismar. From Text to Context: The Turn to History in Modern Judaism. Hanover: Brandeis University Press, 1994.

Schuller, Eileen. "The Dead Sea Scrolls and Jewish-Christian Dialogue." In From Judaism to Christianity: Tradition and Transition, A Festschrift for Thomas H. Tobin, S.J., on the Occasion of His Sixty-fifth Birthday, edited by Patricia Walters, 43-58. Leiden: Brill, 2010.

Schwartz, Barry. "Christian Origins: Historical Truth and Social Memory." In Memory, Tradition, and Text: Use of the Past in Early Christianity, edited by Alan Kirk and Tom Thatcher, 43-78. Atlanta: Society of Biblical Literature, 2005.

Shay, Talia. "Israeli Archaeology-Ideology and Practice." Antiquity 63, no. 241 (1989): $768-72$.

Steinweis, Alan E. Studying the Jew: Scholarly Antisemitism in Nazi Germany. Cambridge: Harvard University Press, 2006.

Trever, John C. The Dead Sea Scrolls: A Personal Account. Upland: Upland Commercial Printers, 1988.

Vos, Johan S. "Antijudaismus/Antisemitismus im Theologischen Wörterbuch zum Neuen Testament." Nederlands Theologisch Tijdschrift 35 (1984): 89-110.

Wexler, Ellen. "The Semantics of Anti-Semitism." Moment Magazine, May 12, 2017. https:// www.momentmag.com/semantics-anti-semitism/.

Wiese, Christian. “'The Best Antidote to Anti-Semitism?? Wissenschaft des Judentums, Protestant Biblical Scholarship, and Anti-Semitism in Germany before 1933." In Modern Judaism and Historical Consciousness: Identities, Encounters, Perspectives, edited by Andreas Gotzmann and Christian Wiese, 145-92. Leiden: Brill, 2007.

Yadin, Yigael. Megillat ha-Miqdash. 3 vols. Jerusalem: The Israel Exploration Society and the Shrine of the Book, 1977.

Yadin, Yigael. The Scroll of the War of the Sons of Light Against the Sons of Darkness. Oxford: Oxford University Press, 1962. 
Yadin, Yigael. The Temple Scroll. 3 Volumes and Supplements. Revised Edition. Jerusalem: The Israel Exploration Society and the Shrine of the Book, 1983. 